\title{
Sex ratio adjustment in birds
}

\author{
Eszter SzÁsz ${ }^{1}$, Dorottya Kiss ${ }^{1} \&$ BalÁzs Rosivall $^{1 *}$
}

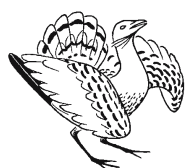

Eszter Szász, Dorottya Kiss \& Balázs Rosivall 2012. Sex ratio adjustment in birds. - Ornis Hungarica 20(1): 26-36. ment is expected to evolve when the fitness benefit an offspring confers to the parents changes with ecological or social factors in a sex-specific way. Though many correlative and experimental studies support these hypotheses, there are still unresolved problems. In our paper, we provide details on the hypotheses related to sex ratio adjustment and explanations for the differences observed in sex ratio patterns between populations and years. Finally, we discuss the importance of sex ratio adjustment for species conservation.

Keywords: environmental effects, life-history, parental quality, sex allocation, sex ratio manipulation, species conservation

Összefoglalás Számos madárfajnál kimutatták, hogy a fészekaljak ivararánya nem véletlenszerü, hanem a szülői vagy környezeti tulajdonságok függvényében változik. Az ivararány-manipuláció néven ismert jelenség magyarázatára számos elméletet dolgoztak ki. Ezek szerint az ivararány-manipuláció azokban az esetekben alakulhat ki az evolúció során, amikor a hím és tojó utódok túlélése, várható szaporodási sikere vagy felnevelési költsége eltér. Bár számos korrelatív és kísérletes vizsgálat támogatja ezeket a hipotéziseket, vannak még az ivararány-manipulációval kapcsolatban megoldatlan kérdések. Cikkünkben részletesen tárgyaljuk az ivararány-manipulációt magyarázó elméleteket, valamint az ivararány-mintázatok populációk és vizsgálati évek közötti eltéréseinek lehetséges okait. Kitérünk a jelenség természetvédelmi jelentőségére is.

Kulcsszavak: életmenet, fajvédelem, ivararány-manipuláció, környezeti hatások, szülői minőség

${ }^{I}$ Behavioural Ecology Group, Department of Systematic Zoology and Ecology, Eötvös Loránd University,

1117 Budapest, Pázmány Péter sétány 1/c.

"corresponding author: rosi@ludens.elte.hu

\section{Introduction}

It has been revealed in a number of species that the sex ratio of the offspring is not random, instead it is related to parental quality and environmental conditions. These patterns are suggested to be adaptive, if the sex with the higher fitness potential is overproduced. This phenomenon is called sex ratio adjustment (or sex ratio manipulation), and it can evolve if the following conditions are met: (1) fitness benefit from male and female offspring varies with parental quality and en- vironmental conditions in a predictable and sex-specific way; (2) the costs and benefits associated with the adjustment have a positive balance. As the predictability of and the difference in the fitness of male and female offspring increases, the selection for and the degree of sex ratio adjustment is also expected to increase (Oddie 1998, West \& Sheldon 2002). Note that the net benefit of adjustment depends on the underlying mechanisms, thus more precise and less costly mechanisms are more likely to evolve and they are expected to result in more biased offspring sex ratios. 
The exact mechanisms of sex ratio adjustment have been undetermined so far. However, it is possible that sex ratio adjustment has evolved multiple times during phylogeny, and thus different mechanisms are at work in different bird species. Nonetheless, in birds, females have been suggested to have more opportunity to adaptively bias the sex ratio of the offspring (Krackow 1995) for the following reasons. Female is the heterogametic sex (i.e. females possess two different, while males possess two similar sex chromosomes), and the sex of the offspring is determined just before ovulation during the first meiotic division. In addition, fertilisation and egg formation also take place inside the female's body. Manipulation at these early stages leads to biased "primary sex ratio" (i.e. biased sex ratio at egg laying). When sex ratio is altered after egg laying, the term "secondary sex ratio adjustment" is used. In the latter, fathers may also be involved (e.g. via sex-specific paternal provisioning). However, the adaptive value of secondary sex ratio adjustment is questionable, since it is achieved by differential mortality of the sexes, instead of differential production of the sexes, which may be beneficial under extreme conditions only (Clutton-Brock 1991).

After molecular sex determination techniques had been developed (Griffiths et al. 1998, Fridolfsson \& Ellegren 1999), sexing the offspring at early stages and thus examining primary sex ratios became possible. The number of studies has been steadily and rapidly growing since then. Today, there is evidence for primary sex ratio adjustment in species from half of the avian orders (Pike \& Petrie 2003), which suggests that this phenomenon is quite widespread in birds. Below, we review the hypotheses related to primary sex ratio adjustment, their implications for conservation biology, and discuss the potential problems arising in this research field.

\section{Frequency-dependence and sex ratio}

Early theories on sex ratios argued that the most common sex ratio, that is 0.5 (i.e. the proportion of males in the population is 0.5 ), is the result of frequency-dependent selection (Düsing 1884). Keeping in mind that in sexually reproducing populations, all the males taken together have exactly the same number of offspring as all the females taken together, it is easy to see that when one sex becomes less abundant it will have on average a greater number of offspring than the sex in majority. Consequently, as Düsing (1884) argued, it is adaptive to produce the rare sex, because this way parents can maximize their fitness. Such frequencydependent sex ratio adjustment should lead to a population sex ratio of 0.5 . However, as Fisher (1930) pointed out, in many species (e.g. in sexually size dimorphic species), the costs of producing or rearing male and female offspring differ. In these species, producing the more costly sex at a population sex ratio of 0.5 causes net fitness loss, because, despite the larger investment, the same fitness benefit is achieved as by producing the less costly sex. When less individual of the more costly sex is produced accordingly, its frequency in the population declines, hence its fitness potential increases. Finally, as a result of frequency-dependent sex ratio adjustment, the proportion of the sexes in the population will be the inverse of the proportion of the production and rearing costs of the sexes (e.g. if males cost $20 \%$ more, there will be $20 \%$ less males in the popula- 
tion). In other words, parents, on average, invest the same amount of energy into male and female offspring. This argument is called the "equal investment hypothesis" or the "Fisher-hypothesis" (Fisher 1930).

\section{Individual variation in brood sex ratio}

The theory of Düsing (1884) and Fisher (1930) does not take into account the individual variation in offspring sex ratio. However, such variation may be adaptive, because of individual variation in factors that may influence offspring fitness in a sex-specific way. Trivers and Willard (1973) were the first who gave prediction for individual offspring sex ratios. Their influential theory was developed for polygynous mating system.

The Trivers-Willard-hypothesis (TWH) has the following assumptions: (1) body condition of the offspring is correlated with body condition of the mother; (2) body condition of the offspring predicts their future reproductive success; (3) body condition has a disproportionately greater impact on the reproductive success of males, thus maternal body condition has a disproportionately greater impact on the future reproductive success of male offspring. The latter is a consequence of polygyny, since males in superior body condition are favoured both in male-male competition and during mate choice, resulting in a skewed genetic contribution to the next generation. It means that male reproductive success is highly variable, whereas female reproductive success is less variable. If the above assumptions are met, one may expect that mothers in better than average body condition overproduce sons, whereas mothers in poorer than average body condition overproduce daughters to maximize their net fitness return. This prediction not only holds for polygynous species, but also for many socially monogamous ones. Namely, in most bird species, extra-pair copulation and facultative polygyny occur (Griffith et al. 2002), thus the reproductive success of males may vary more than that of females. Indeed, in the Tree swallow (Tachycineta bicolor), where extra-pair young add up to the $38-76 \%$ of all the offspring (Whittingham \& Dunn 2000), a positive relationship has been found between maternal body condition and the proportion of sons in the brood.

The logic of the TWH can be extended to any parental or environmental attribute that may have sex-dependent relationship with offspring reproductive success. Parents of good quality, or in better breeding environment, should overproduce the sex that has a more variable reproductive success along the attribute of the parents or the breeding environment, whereas parents of poor quality, or in a poorer environment, should overproduce the sex that has a less variable reproductive success along the given attribute. Such attributes include maternal age, maternal mating status (i.e. primary or secondary female), paternal attractiveness (e.g. plumage colouration), parental social rank and parental genetic quality (manifested e.g. in body size or immune capacity), food availability, and also timing of breeding (for a review see Hasselquist \& Kempenaers 2002). Note that the listed attributes are not independent from each other, making it hard to determine their relative importance in sex ratio adjustment. Below, we try to give an overview about the most significant hypotheses that follow the Trivers-Willard-logic.

Perhaps the "male attractiveness hypothesis" (Burley 1981, 1986) has the clearest theoretical background: (1) traits that determine sexual attractiveness of males are 
heritable; (2) females prefer the attractive males during mate choice; (3) attractivity thus influences the reproductive success of males disproportionately more than that of females. Consequently, one may expect that females mated to more attractive males overproduce sons, whereas females mated to less attractive males overproduce daughters. Quite a few studies showing a positive correlation between feather ornamentation and brood sex ratio support this hypothesis (correlative studies: Collared flycatcher, $\mathrm{Fi}$ cedula albicollis, Ellegren et al. 1996, Blue tit, Cyanistes caeruleus, Griffith et al. 2003; experimental studies: Zebra finch, Taeniopygia guttata, Burley 1981, 1986, Blue tit, Sheldon et al. 1999, Peafowl, Pavo cristatus, Pike \& Petrie 2005). In addition, in species, where offspring body size is correlated with paternal body size and large body size is preferred during mate choice, females mated to larger male often overproduced sons (Great tit, Parus major, Kölliker et al. 1999, Rhinoceros auklet, Cerorhinca monocerata, Addison et al. 2008).

The mating status of the mother and the sex ratio of the brood also correlated in some species: broods of primary females contained more sons than broods of secondary females (Yellow-headed blackbird, Xanthocephalus xanthocephalus, Patterson \& Emlen 1980, Oriental reed warbler, $A c$ rocephalus orientalis, Nishiumi 1998, Great reed warbler, A. arundinaceus, Westerdahl et al. 2000). Because males are predominantly feeding at the primary nests, and, as a result of the polygynous mating system, male offspring are likely to profit more from the extra paternal investment, the observed patterns seem to be adaptive.

Numerous studies provide evidence for the "maturation time hypothesis" (Daan et al. 1996), which suggests that in those species, where timing of the first breeding is sex-specifically related to the date of fledging, a shift in the brood sex ratio during the breeding season may be adaptive. Accordingly, in species where the timing of the first breeding is influenced by fledging date in males, but not in females (e.g. the Common kestrel, Falco tinnunculus, Dijkstra et al. 1990, the Lesser kestrel, F. naumanni, Tella et al. 1996, and the American kestrel, F. sparverius, Smallwood \& Smallwood 1998), male offspring were overproduced early in the breeding season, and female offspring were overproduced late in the breeding season. A seasonal brood sex ratio shift in the opposite direction was found in species, where the age at first breeding is advanced by early fledging in females, but not in males (see e.g. the Marsh harrier, Circus aeruginosus, the Goshawk, Accipiter gentilis, the Sparrowhawk, A. nisus, Daan et al. 1996).

There are examples for seasonal brood sex ratio shift in passerines too, but in these cases the adaptive reason may be other than a sex-difference in maturation time. For example, in the Eastern kingbird (Tyrannus tyrannus), the early broods contained disproportionately more sons, which can be explained by the decline in recruitment probability with fledging date in males and the lack of this relationship in females (Dolan et al. 2009). In the Brown songlark (Cincloramphus cruralis), early broods contained a surplus of daughters (Isaksson et al. 2010). Although, the authors had no information on the effect of fledging date on recruitment probability, they argued that the pattern may be the result of male offspring being more sensitive to the environment or more costly to rear (see below).

The TWH and the other hypotheses discussed above are based on sex differences in the future reproductive success of the 
offspring. However, the net fitness benefit through male and female offspring may also be influenced by the sex-specific survivorship of the offspring. Therefore, under unfavourable conditions, it may be beneficial for the mothers to produce the less sensitive sex, when sensitivity to rearing environment differs between male and female offspring (Råberg et al. 2005). Hereafter, we refer to this argument as the "sensitivity hypothesis". It is supported, for example, by some studies on Zebra finches. Under poor food conditions, female offspring grew slower (Martins 2004) and, accordingly, mothers produced male-biased broods (Bradbury \& Blakey 1998, Kilner 1998).

All the above hypotheses on brood sex ratio overlook the fact that birds usually breed multiple times during their lifetime, making the trade-off between the current and the future reproductive event another factor that may influence the manipulation of brood sex ratio. This is because, as we mentioned earlier, producing or rearing male and female offspring may impose different costs on the parents. The relative cost of the sexes is usually estimated by the difference in their body size or body weight (Dijkstra et al. 1998, Ewen et al. 2001), but egg size (Cordero et al. 2000, 2001), food provisioning rate (Suorsa et al. 2003) and maternal stress hormone level during rearing (Addison et al. 2008) has also been reported to vary with offspring sex or sex ratio. Whenever there is a difference in the amount of investment required by male and female offspring, mothers in poorer body condition may overproduce the less demanding sex to ensure their own survival and future breeding. This is the "cost of reproduction hypothesis" for sex ratio adjustment (Cockburn et al. 2002). In line with the hypothesis, the smaller sex was overproduced by mothers in poor body condition (Lesser black-backed gull, Larus fuscus, Nager et al. 1999, Great skua, Stercorarius skua, Kalmbach et al. 2001, Japanese quail, Coturnix japonica, Correa et al. 2011).

In some bird species, the net fitness benefit through male and female offspring is influenced not only by sex-specific survivorship and reproductive success but also by sex-specific difference in site fidelity (i.e. offspring of the "philopatric sex" remain on the natal territory, while offspring of the "dispersive sex" leave and breed further away). The "local resource competition hypothesis" (LRC, Cockburn et al. 2002) says that in case of competition for limited resources between family members, it is beneficial for the mothers to produce the dispersive sex. Indeed, such a pattern has been found in the Western bluebird (Sialia mexicana, Dickinson 2004) and in the Bell miner (Manorina melanophrys, Ewen et al. 2003). Theoretically, it is possible that the limited resource is one of the sexes. This special case is called the "local mate competition hypothesis" (Hamilton 1967). The other side of the coin is described by the "local resource enhancement hypothesis" (LRE, Cockburn et al. 2002). It can be applied to cooperative breeders, where offspring of the philopatric sex help their parents in rearing the subsequent broods. Accordingly, the LRE says that as long as the presence of the helpers provides fitness advantage for the parents, selection favours the production of the philopatric sex. However, the fitness benefit of the helpers is decreasing as their number is increasing, because resources may become limited and this means that the LRC comes into effect. The complementary nature of the LRC and LRE can be best illustrated by the classical study on the Seychelles warbler (Acrocephalus sechellensis, Komdeur et al. 1997). In this species, female offspring stay 
on the natal territory to help, while male offspring disperse. When parents bred on high quality territory and had few helpers, philopatric daughters, whereas when parents bred on low quality territory or had enough helpers, dispersive sons were produced.

\section{Complications of studying sex ratio adjustment}

Though each hypothesis is supported by a number of studies, there are unresolved problems concerning sex ratio adjustment. Apart from the lack of knowledge on the mechanism, these are: (1) several studies have not found any relationship between the examined factors and offspring sex ratio or found a relationship, which contradicts the predictions; (2) results often differ between populations of the same species or between study years of the same population. The reasons behind these two problems overlap. (i) Considering the complex physiology and life-history of birds, it is very likely that a number of factors are involved in sex ratio adjustment, which act simultaneously and sometimes antagonistically and thus may cancel each other's effect (Frank 1990, Cockburn et al. 2002). (ii) Sex ratio adjustment is often predicted without information on whether parental or environmental quality has a sex-dependent effect on offspring fitness in the given study population, though this would be a prerequisite for sex ratio adjustment (Hasselquist \& Kempenaers 2002). (iii) It is also rarely investigated before the authors make predictions, whether offspring impose sex-dependent costs on the parents. (iv) The sample sizes are often too small to obtain results with sufficient power (Rosivall 2008). (v) In several cases, the applied methodology does not allow the correct examination of sex ratio adjustment, or dif- fers between studies making comparisons difficult. (vi) The fitness benefit of sex ratio adjustment may significantly vary with ecological or social conditions, and thus the sex ratio patterns are expected to differ between years and populations.

Collared flycatchers provide a good example how sex ratio patterns may differ between populations. In a Swedish population, males with the larger forehead patch had male-biased broods (Ellegren et al. 1996). On the contrary, in a Hungarian population of the species, there was no such a relationship between male phenotype and brood sex ratio (Rosivall et al. 2004). A likely explanation for this pattern is that the information content of male plumage characteristics differs between the two populations. Specifically, the size of the forehead patch is condition-dependent in the Swedish population (Gustafsson et al. 1995, Ellegren et al. 1996), while it is not in the Hungarian population (Hegyi et al. 2002), even though it seems to be heritable at both locations (Qvarnström 1999, Hegyi et al. 2002). Taking together, forehead patch size related sex ratio adjustment may be beneficial for Collared flycatcher females in the Swedish population, but not or less beneficial in the Hungarian population.

Sex ratio patterns differed also between Blue tit populations. In a Swedish population of the species, males with more UV reflective crown had more sons, and the UV reflectance of the crown had a positive relationship with male viability (Sheldon et al. 1999, Griffith et al. 2003). Pairs of more viable male Blue tits biased their brood sex ratio towards sons in another Swedish population too (Svensson \& Nilsson 1996). However, at other locations, neither male survival (United Kingdom, Leech et al. 2001) nor male crown colouration (France, Dreiss 
et al. 2006) showed relationship with brood sex ratio. More recent results suggest that the relationship between male crown colouration and brood sex ratio is even more complex than it had been thought before. In an Austrian Blue tit population, females biased their brood sex ratio towards sons when paired to juvenile male with more UV reflective crown or adult male with less UV reflective crown (Delhey et al. 2007). Delhey et al. (2007) argued that this pattern is consistent with the finding that the information content of male plumage characteristics may differ between age categories. UV reflectance correlated positively with testosterone level among juvenile males, while correlated negatively with testosterone level and success in siring extra-pair young among adult males. Because of methodological differences between the studies (i.e. interaction between crown colouration and age was apparently not examined in the former studies), we can only speculate about the generality of the more recent results. In addition, methodological differences make it difficult to interprete the lack of relationship between male crown colouration and brood sex ratio in the French population. In this population, UV colouration was measured on two superimposed feathers collected from the crown of each male (Dreiss et al. 2006), while the other studies measured colouration on the crown of the living birds (Sheldon et al. 1999, Delhey et al. 2007).

Studies on Great tit populations also yielded mixed results. In a Swiss population of the species, male body size had a positive relationship with the proportion of sons in the brood (Kölliker et al. 1999), while in a British population, using 5 years of data, no such a relationship was found (Radford $\&$ Blakey 2000). The latter study revealed some significant relationships when years were analysed separately, but strength and direction of the relationships did not show consistency across years (Radford \& Blakey 2000). This can be either the result of the relatively low sample sizes per year or the yearly variation in the fitness benefits of sex ratio adjustment.

To resolve the contradictions and to improve our understanding of sex ratio adjustment, studies with larger sample sizes and consistent methods on multiple populations and multiple years are required. However, we have to note that even if we have such studies, our understanding of the evolution of sex ratio adjustment will be hampered by the difficulty to determine the real factors involved, because different hypotheses often give the same prediction. For instance, according to the "male attractiveness hypothesis", pairs of more attractive males rather produce sons, whereas pairs of less attractive males rather produce daughters. However, when attractivity is positively correlated with body condition or the quality of paternal care and male offspring are more sensitive to the environment or more costly to rear, the "sensitivity hypothesis" and the "cost of reproduction hypothesis" predict the same pattern, albeit the selective forces are different in each of the three scenarios.

\section{Implications of sex ratio adjust- ment for species conservation}

The survival chance of small populations of endangered species may be influenced by sex ratio adjustment. Therefore, the knowledge and application of the relevant theories may significantly contribute to the success of in situ and ex situ species conservation programs. The measures taken in the case of the Kakapo (Strigops habroptilus) pro- 
vide an excellent example. The Kakapo is a sexually size dimorphic, lek polygynous, endemic parrot of New Zealand. The number of individuals had dropped dramatically by the 1990s, because this flightless, ground nesting species had been an easy prey to the introduced mammals. Moreover, predation rate was higher for females, because only females incubate and rear the nestlings. As a result, the population sex ratio became male-biased (Clout et al. 2002). In 1989, a recovery program was started. The females were provided with ad libitum supplementary food to increase their bodyweight above the threshold necessary for breeding. However, as a result of this food regime, the body condition of the females improved so much that it was accompanied with male-biased offspring sex ratios (Clout et al. 2002). Considering the larger size and the greater variance in the reproductive success of males in this lek polygynous species, this result perfectly fits to the prediction of the TWH, the "sensitivity hypothesis" and the "cost of reproduction hypothesis". The observed sex ratio bias was suggested to hinder population growth and increase the risk of extinction (Robertson et al. 2006). Based on these findings, a new food regime has been developed that keeps female body weight above the breeding threshold, but prevents unbalanced offspring sex ratios (Robertson et al. 2006).

The Eurasian treecreeper (Certhia familiaris) is not an endangered species, however, its case is very relevant because habitat destruction is one of the most important issues of conservation biology. It alters landscape structure, the proportion of open areas and edges, and also the composition of the community. Therefore, members of the community may have to breed under unfavourable conditions, and this may have an impact on offspring sex ratio. The Eurasian treecreeper, which prefers old, continuous and diverse forests, produced female-biased broods when breeding in edges (Suorsa et al. 2003). This pattern seems to be adaptive, because the main food item of the species was scarce in the edges of the forest fragments and male nestlings being larger and suffering higher mortality before fledging are likely to be more costly to rear and more sensitive to the poor environment (Suorsa et al. 2003). Similar offspring sex ratio biases in small habitat fragments, either due to sexspecific sensitivity or sex-specific site fidelity, would increase the extinction risk of an endangered species.

\section{Concluding remarks}

Despite the problems that have arisen concerning sex ratio adjustment, this phenomenon seems to be quite widespread in birds (West \& Sheldon 2002). Though further studies with larger sample sizes and consistent methods on multiple populations and years are clearly needed, the knowledge that has accumulated up to present is already valuable. For example, the application of the related theories may help to design breeding programs and conservation measures which promote the survival of threatened species by optimizing offspring sex ratios (Wedekind 2002).

\section{Acknowledgement}

We thank Miklós Laczi, János Török and Orsolya Wade for their comments on the MS. During the writing of this paper B. R. was supported by the Hungarian Research Fund (PD75481, F68295). 


\section{References}

Addison, B. A., Kitaysky, A. S. \& Hipfner, J. M. 2008. Sex allocation in a monomorphic seabird with a single-egg clutch: test of the environment, mate quality, and female condition hypotheses. - Behavioral Ecology and Sociobiology 63: 135-141.

Bradbury, R. B. \& Blakey, J. K. 1998. Diet, maternal condition, and offspring sex ratio in the Zebra finch, Poephila guttata. - Proceedings of the Royal Society of London B 265: 895-899.

Burley, N. 1981. Sex ratio manipulation and selection for attractiveness. - Science 211: 721-722.

Burley, N. 1986. Sex-ratio manipulation in color-banded populations of Zebra finches. - Evolution 40: 1191-1206.

Clout, M. N., Elliott, G. P. \& Robertson, B. C. 2002. Effects of supplementary feeding on the offspring sex ratio of Kakapo: a dilemma for the conservation of a polygynous parrot. - Biological Conservation 107: 13-18.

Clutton-Brock, T. H. 1991. The evolution of parental care. - Princeton University Press, Princeton

Cockburn, A., Legge, S. \& Double, M. C. 2002. Sex ratios in birds and mammals: can the hypotheses be disentangled? - in: Hardy, I. C. W. (ed.) Sex Ratios: Concepts and Research Methods. - Cambridge University Press, Cambridge pp. 266-286.

Cordero, P. J., Griffith, S. C., Aparicio, J. M. \& Parkin, D. T. 2000. Sexual dimorphism in House sparrow eggs. - Behavioral Ecology and Sociobiology 48: 353-357.

Cordero, P. J., Viñuela, J., Aparicio, J. M. \& Veiga, J. P. 2001. Seasonal variation in sex ratio and sexual egg dimorphism favouring daughters in first clutches of the Spotless starling. - Journal of Evolutionary Biology 14: 829-834.

Correa, S. M., Horan, C. M., Johnson, P. A. \& AdkinsRegan, E. 2011. Copulatory behaviors and body condition predict post-mating female hormone concentrations, fertilization success, and primary sex ratios in Japanese quail. - Hormones and Behavior 59: 556-564.

Daan, S., Dijkstra, C. \& Weissing, F. J. 1996. An evolutionary explanation for seasonal trends in avian sex ratios. - Behavioral Ecology 7: 426-430.

Delhey, K., Peters, A., Johnsen, A. \& Kempenaers, B. 2007. Brood sex ratio and male UV ornamentation in Blue tits (Cyanistes caeruleus): correlational evidence and an experimental test. - Behavioral Ecology and Sociobiology 61: 853-862.

Dickinson, J. L. 2004. Facultative sex ratio adjustment by Western bluebird mothers with stay-athome helpers-at-the-nest. - Animal Behaviour 68: 373-380.
Dijkstra, C., Daan, S. \& Buker, J. B. 1990. Adaptive seasonal variation in the sex-ratio of kestrel broods. - Functional Ecology 4: 143-147.

Dijkstra, C., Daan, S. \& Pen, I. 1998. Fledgling sex ratios in relation to brood size in size-dimorphic altricial birds. - Behavioral Ecology 9: 287-296.

Dolan, A. C., Murphy, M. T., Redmond, L. J. \& Duffield, D. 2009. Maternal characteristics and the production and recruitment of sons in the Eastern kingbird (Tyrannus tyrannus). - Behavioral Ecology and Sociobiology 63: 1527-1537.

Dreiss, A., Richard, M., Moyen, F., White, J., Møller, A. P. \& Danchin, E. 2006. Sex ratio and male sexual characters in a population of Blue tits, Parus caeruleus. - Behavioral Ecology 17: 13-19.

Düsing, C. 1884. Die Regulierung des Geschlechtsverhältnisses bei der Vermeherung der Menschen, Tiere und Pflanzen. - Jenaische Zeitschrift für Naturwissenschaft 17: 593-940.

Ellegren, H., Gustafsson, L. \& Sheldon, B. C. 1996. Sex ratio adjustment in relation to paternal attractiveness in a wild bird population. - Proceedings of the National Academy of Sciences, USA 93: 11723-11728.

Ewen, J. G., Clarke, R. H., Moysey, E., Boulton, R. L., Crozier, R. H. \& Clarke, M. F. 2001. Primary sex ratio bias in an endangered cooperatively breeding bird, the Black-eared miner, and its implications for conservation. - Biological Conservation 101: 137-145.

Ewen, J. G., Crozier, R. H., Cassey, P., Ward-Smith, T., Painter, J. N., Robertson, R. J., Jones, D. A. \& Clarke, M. F. 2003. Facultative control of offspring sex in the cooperatively breeding Bell miner, Manorina melanophrys. - Behavioral Ecology 14: 157-164.

Fisher, R. A. 1930. The genetical theory of natural selection. - Clarendon Press, Oxford

Frank, S. A. 1990. Sex allocation theory for birds and mammals. - Annual Review of Ecology and Systematics 21: 13-55.

Fridolfsson, A. K. \& Ellegren, H. 1999. A simple and universal method for molecular sexing of non-ratite birds. - Journal of Avian Biology 30: 116-121.

Griffiths, R., Double, M. C., Orr, K. \& Dawson, R. J. G. 1998. A DNA test to sex most birds. - Molecular Ecology 7: 1071-1075.

Griffith, S. C., Owens, I. P. F. \& Thuman, K. A. 2002. Extra pair paternity in birds: a review of interspecific variation and adaptive function. - Molecular Ecology 11: 2195-2212.

Griffith, S. C., Örnborg, J., Russell, A. F., Andersson, S. \& Sheldon, B. C. 2003. Correlations between 
ultraviolet coloration, overwinter survival and offspring sex ratio in the Blue tit. - Journal of Evolutionary Biology 16: 1045-1054.

Gustafsson, L., Qvarnström, A. \& Sheldon, B. C. 1995. Trade-offs between life-history traits and a secondary sexual character in male Collared flycatchers. - Nature 375: 311-313.

Hamilton, W. D. 1967. Extraordinary Sex Ratios. - Science 156: 477-488.

Hasselquist, D. \& Kempenaers, B. 2002. Parental care and adaptive brood sex ratio manipulation in birds. - Philosophical Transactions of the Royal Society of London B 357: 363-372.

Hegyi, G., Török, J. \& Tóth, L. 2002. Qualitative population divergence in proximate determination of a sexually selected trait in the Collared flycatcher. - Journal of Evolutionary Biology 15: 710-719.

Isaksson, C., Magrath, M. J. L., Groothuis, T. G. G. \& Komdeur, J. 2010. Androgens during development in a bird species with extremely sexually dimorphic growth, the Brown songlark, Cicloramphus cruralis. - General and Comparative Endocrinology 165: 97-103.

Kalmbach, E., Nager, R. G., Griffiths, R. \& Furness, R. W. 2001. Increased reproductive effort results in male-biased offspring sex ratio: an experimental study in a species with reversed sexual size dimorphism. - Proceedings of the Royal Society of London B 268: 2175-2179.

Kilner, R. 1998. Primary and secondary sex ratio manipulation by Zebra finches. - Animal Behaviour 56: 155-164.

Komdeur, J., Daan, S., Tinbergen, J. \& Mateman, C. 1997. Extreme adaptive modification in sex ratio of the Seychelles warbler's eggs. - Nature 385: 522-525.

Kölliker, M., Heeb, P., Werner, I., Mateman, A. C., Lessells, C. M. \& Richner, H. 1999. Offspring sex ratio is related to male body size in the Great tit (Parus major). - Behavioral Ecology 10: 68-72.

Krackow, S. 1995. Potential mechanisms for sex ratio adjustment in mammals and birds. - Biological Reviews of the Cambridge Philosophical Society 70: 225-241.

Leech, D. I., Hartley, I. R., Stewart, I. R. K., Griffith, S. C. \& Burke, T. 2001. No effect of parental quality or extrapair paternity on brood sex ratio in the Blue tit (Parus caeruleus). - Behavioral Ecology 12: 674-680.

Martins, T. L. F. 2004. Sex-specific growth rates in Zebra finch nestlings: a possible mechanism for sex ratio adjustment. - Behavioral Ecology 15: 174-180.

Nager, R. G., Monaghan, P., Griffiths, R., Houston, D. C. \& Dawson, R. 1999. Experimental demonstra- tion that offspring sex ratio varies with maternal condition. - Proceedings of the National Academy of Sciences, USA 96: 570-573.

Nishiumi, I. 1998. Brood sex ratio is dependent on female mating status in polygynous Great reed warblers. - Behavioral Ecology and Sociobiology 44: 9-14.

Oddie, K. 1998. Sex discrimination before birth. - Trends in Ecology \& Evolution 13: 130-131.

Patterson, C. B. \& Emlen, J. M. 1980. Variation in nestling sex-ratios in the Yellow-headed blackbird. - American Naturalist 115: 743-747.

Pike, T. W. \& Petrie, M. 2003. Potential mechanisms of avian sex manipulation. - Biological Reviews of the Cambridge Philosophical Society 78: 553574.

Pike, T. W. \& Petrie, M. 2005. Offspring sex ratio is related to paternal train elaboration and yolk corticosterone in Peafowl. - Biology Letters 1: 204-207.

Qvarnström, A. 1999. Genotype-by-environment interactions in the determination of the size of a secondary sexual character in the Collared flycatcher (Ficedula albicollis). - Evolution 53: 1564-1572.

Råberg, L., Stjernman, M. \& Nilsson, J. Å. 2005. Sex and environmental sensitivity in Blue tit nestlings. - Oecologia 145: 496-503.

Radford, A. N. \& Blakey, J. K. 2000. Is variation in brood sex ratios adaptive in the Great tit (Parus major)? - Behavioral Ecology 11: 294-298.

Robertson, B. C., Elliott, G. P., Eason, D. K., Clout, M. N. \& Gemmell, N. J. 2006. Sex allocation theory aids species conservation. - Biology Letters 2: 229-231.

Rosivall, B. 2008. Contradictory results in sex ratio studies: populations do not necessarily differ. - Behavioral Ecology and Sociobiology 62: 1037-1042.

Rosivall, B., Török, J., Hasselquist, D. \& Bensch, S. 2004. Brood sex ratio adjustment in Collared flycatchers (Ficedula albicollis): results differ between populations. - Behavioral Ecology and Sociobiology 56: 346-351.

Sheldon, B. C., Andersson, S., Griffith, S. C., Örnborg, J. \& Sendecka, J. 1999. Ultraviolet colour variation influences Blue tit sex ratios. - Nature 402: 874-877.

Smallwood, P. D. \& Smallwood, J. A. 1998. Seasonal shifts in sex ratios of fledgling American kestrels (Falco sparverius paulus): the early bird hypothesis. - Evolutionary Ecology 12: 839-853.

Suorsa, P., Helle, H., Huhta, E., Jäntti, A., Nikula, A. \& Hakkarainen, H. 2003. Forest fragmentation is associated with primary brood sex ratio in the 
Treecreeper (Certhia familiaris). - Proceedings of the Royal Society of London B 270: 2215-2222.

Svensson, E. \& Nilsson, J. Å. 1996. Mate quality affects offspring sex ratio in Blue tits. - Proceedings of the Royal Society of London B 263: 357-361.

Tella, J. L., Donazar, J. A., Negro, J. J. \& Hiraldo, F. 1996. Seasonal and interannual variations in the sex-ratio of Lesser kestrel Falco naumanni broods. - Ibis 138: 342-345.

Trivers, R. L. \& Willard, D. E. 1973. Natural selection of parental ability to vary the sex ratio of offspring. - Science 179: 90-92.

Wedekind, C. 2002. Manipulating sex ratios for conservation: short-term risks and long-term benefits. - Animal Conservation 5: 13-20.
West, S. A. \& Sheldon, B. C. 2002. Constraints in the evolution of sex ratio adjustment. - Science 295: $1685-1688$.

Westerdahl, H., Bensch, S., Hansson, B., Hasselquist, D. \& von Schantz, T. 2000. Brood sex ratios, female harem status and resources for nestling provisioning in the Great reed warbler (Acrocephalus arundinaceus). - Behavioral Ecology and Sociobiology 47: 312-318.

Whittingham, L. A. \& Dunn, P. O. 2000. Offspring sex ratios in Tree swallows: females in better condition produce more sons. - Molecular Ecology 9: 1123-1129.

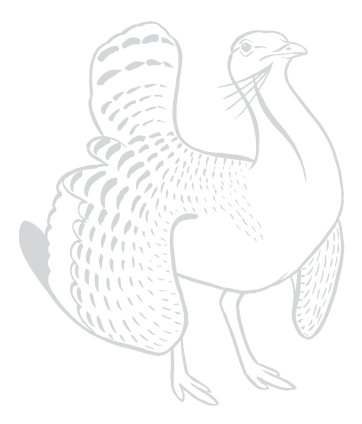

